\title{
Three new species of Ponthieva (Orchidaceae, Spiranthoideae) from Colombia and Venezuela
}

\author{
Dariusz L. Szlachetko • Marta Kolanowska
}

Received: 20 December 2012/ Accepted: 16 April 2013/Published online: 3 May 2013

(C) The Author(s) 2013. This article is published with open access at Springerlink.com

\begin{abstract}
Three new species of Ponthieva, P. camargoi, $P$. castanedoi, and P. cesarensis are described and illustrated based on Colombian and Venezuelan material. The comparisons of the floral characters of the new entities and closely allied species are illustrated. The information about habitat and ecology of all three species is provided and their distribution map is presented.
\end{abstract}

Keywords Colombia $\cdot$ Orchidaceae $\cdot$ Spiranthoideae $\cdot$

Venezuela

\section{Introduction}

The genus Ponthieva was described by Robert Brown (1813) based on Neottia glandulosa Sims characterised by the rosulate, shortly petiolate leaves, the glandular-hairy ovary and floral bracts, the small flowers arranged in a loose raceme, and the clawed petals and lip, which are connivent to the gynostemium.

The generic separateness of Ponthieva is not in doubt despite the general discussion about the infratribal classification of Cranichidinae (Szlachetko 1995; Salazár et al. 2003, 2009). The unique characters of Ponthieva, which easily distinguish them from other cranichioid orchids are the petiolate, thin leaves, membranaceous floral bracts, often pubescent sepals with free or variously connate lateral sepals, strongly asymmetric petals adnate to the gynostemium and inserted on it and fleshy, usually

\section{L. Szlachetko · M. Kolanowska $(\square)$}

Department of Plant Taxonomy and Nature Conservation,

University of Gdańsk ul, Wita Stwosza 59, 80-308 Gdańsk,

Poland

e-mail: martakolanowska@wp.pl prominently clawed, relatively small lip. The gynostemium is short without column-foot, the wing-like staminodes are fused with the filament and with the stigma margins forming a prominent dorsal clinandrium, the single, detachable viscidium is rather small and the triangular, acute hamulus is directed towards the anther (Szlachetko and Rutkowski 2000).

Species of Ponthieva are widely distributed in Neotropics from the USA (Alabama, South Carolina, North Carolina, Florida, Louisiana, Virginia) to Argentina, with the greatest diversity reported from Ecuador. The core of the genus are terrestrial plants growing in humid forests, but muscicolous specimens can be also found on rocks or branches (Ames and Correll 1952; Carnevali et al. 2003). So far, 17 species of Ponthieva have been reported from Colombia, most of them grow in the montane regions above $2,000 \mathrm{~m}$. Just two species, $P$. gracilis and $P$. maculata, were reported from the lowlands (Ortiz and Uribe 2007).

The comprehensive revision of the herbarium material stored in COL revealed the existence of three distinguished species of Ponthieva, which are described here as new.

\section{Materials and methods}

Dried herbarium specimens were examined according to the standard procedures. Every studied sheet was photographed and the data from the labels were taken. Both vegetative and generative characters of each plant were studied. The shape and size of the leaves were examined first. Then the construction of the inflorescence and the shape and size of the floral bracts were studied. The morphology of flower was examined after its boiling using a stereomicroscope. At the end, the measurements and the surface of each floral element were studied. 
Acronyms for herbaria followed Index Herbariorum. The CorelDraw v.12 software was used for the preparation of the distribution maps.

\section{Taxonomic treatment}

Ponthieva camargoi Szlach. \& Kolan. sp. nov. (Fig. 1)

This species appears to be related to $P$. pseudoracemosa Garay and $P$. racemosa (Walter) C.Mohr, but unlike both of them, its lip is subsessile and devoided of any callus.
Type G. Huertas \& L.A. Camargo G. 6971-Colombia, Dept. Santander, Mpio. La Paz. Cordillera Oriental. Alrededores del Hoyo del Aire, alt. 1,943 m (7 Nov 1975), (COL! holotype).

Plants to $50 \mathrm{~cm}$ tall. Leaves numerous, basal, rosulate, petiolate; petiole to $3 \mathrm{~cm}$ long, narrow; blade to $10 \mathrm{~cm}$ long and $3 \mathrm{~cm}$ wide, ovate-lanceolate to oblanceolate, acute. Scape erect, slender to relatively stout, glandular above lower third, otherwise glabrous, with up to six cauline sheaths. Flowers small. Floral bracts to $15 \mathrm{~mm}$ long, lanceolate, glandular. Pedicellate ovary to $9 \mathrm{~mm}$ long, densely glandular. Sepals almost glabrous. Dorsal
Fig. 1 Ponthieva camargoidissected perianth. a Dorsal sepal, b petal, c lateral sepal, d lip, e lip (side view). Scale bar $3 \mathrm{~mm}$ [holotype; drawn by P. Baranow]
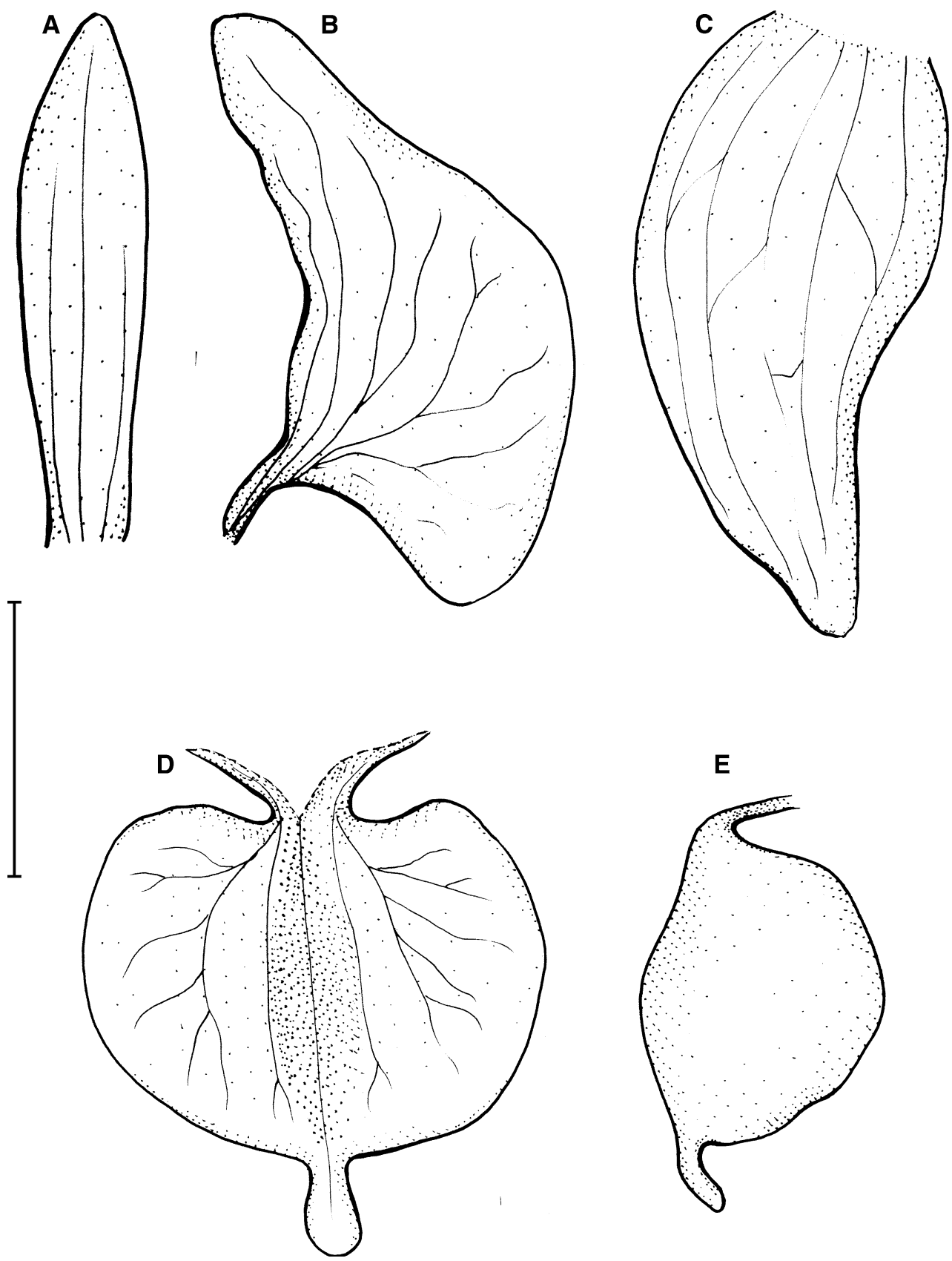
sepal $6 \mathrm{~mm}$ long, $1.5 \mathrm{~mm}$ wide, ligulate, obtuse, obscurely 3-nerved. Lateral sepals $7 \mathrm{~mm}$ long, $3 \mathrm{~mm}$ wide, ovatelanceolate, subobtuse, somewhat falcate, free to the base, 5-nerved. Petals clawed; claw-free part $1.5 \mathrm{~mm}$ long, narrow; lamina $7 \mathrm{~mm}$ long, $3.2 \mathrm{~mm}$ wide, obliquely ellipticovate in the lower part, ligulate above, obtuse at both ends. Lip subsessile; lamina $5.2 \mathrm{~mm}$ long in total, $5.5 \mathrm{~mm}$ wide when spread, obreniform in general outline, subcordate at the base, concave in the centre, glabrous, nerves 5, branching, apical projection $1.2 \mathrm{~mm}$ long and $0.5 \mathrm{~mm}$ wide, linear-ligulate, obtuse. Gynostemium $5 \mathrm{~mm}$ long.

Etymology Dedicated to L.A. Camargo, co-collector of the type specimen.

Distribution, habitat and ecology Found in the northern part of Andean Central and Eastern Cordilleras (Fig. 2) at about $1,235-2,100 \mathrm{~m}$ in premontane forest.

Taxonomic notes This species appears to be quite common in Colombia, and most probably in neighbouring countries, but was not separable from its closest relatives, i.e., P. pseudoracemosa Garay and P. racemosa (Lindl.) Rchb.f. It is easily distinguished from both species mentioned by having ecallose, subsessile lip (Fig. 3).

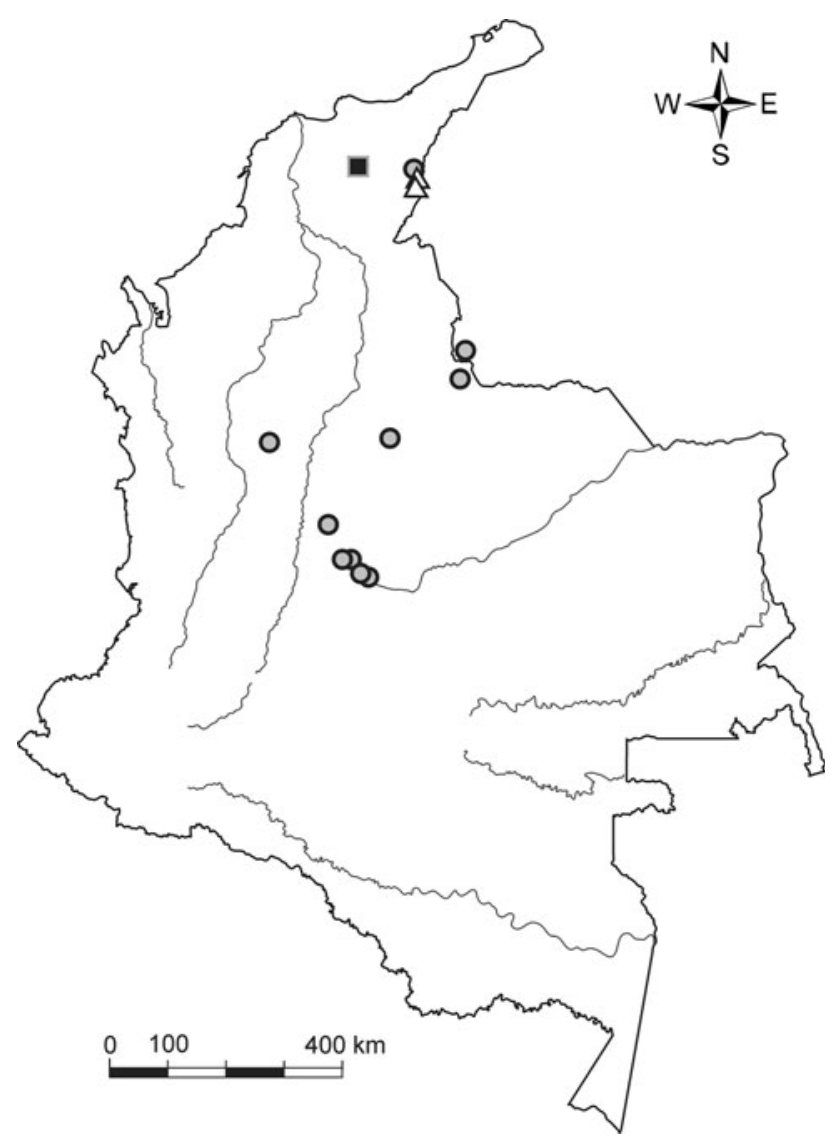

Fig. 2 Distribution of Ponthieva camargoi (circle), P. castanedoi (square), P. cesarensis (triangle) in Colombia
Representative specimens G. Gutierrez V. 1035-Colombia, Dept. Antioquia. Cordillera Central. A orillas de la Carretera entre Medellín y Guarne, alt. 1,500-1,900 m (5 May 1946), (COL!);O. Rivera Diaz, N.J. Garzon \& C.A. Vargas 2936-Colombia, Dept. Cesar: Mpio. Agustin Codazzi, Serrania de Perijá. Vereda Siete de Agosto. Colecciones desde la base de la cuchilla Macho Solo en margen del Rio Guajirita, y ascendiendo hacia la finca cafeteria El Oasis, en sector degradados, sometidos a quemas, $9^{\circ} 57^{\prime} 11.1^{\prime \prime}-33.2^{\prime \prime} \mathrm{N}, 73^{\circ} 02^{\prime} 46.4^{\prime \prime}-03^{\prime} 20.9^{\prime \prime} \mathrm{W}$, alt. 1,235-1,662 m (12 Dec 2005), (COL!); M. Chaparro, H.A. Bernal, R. Bernal, Obando, C. Rodriguez \& D. Higuera 27-Colombia, Dept. Cundinamarca, Mpio. Albán, Granjas del Padre Luna. Bosque al borde de el quebrada La Maria, $4^{\circ} 53^{\prime} \mathrm{N}, 74^{\circ} 26^{\prime} \mathrm{W}$, alt. $1,800 \mathrm{~m}$ (16 Apr 2001), (COL!); Philipson, J.M. Idrobo \& A. Fernandez 1289-Colombia, Dept. Cundinamarca, Mpio. Chipaque, Road from Bogotá to Villavicencio, $2 \mathrm{~km}$ below Chipaque, alt. 2,200 m (31 Oct 1949), (COL!); L. Uribe U. 4597-Colombia, Dept. Cundinamarca, Mpio. Caqueza, Caqueza, acueducto de la Planta Electrica, alt. 1,700 m (26 Nov 1963), (COL!); L. Uribe U. 4615-Colombia, Dept. Cundinamarca, Mpio. Quetame, alt. 1,500 m (28 Nov 1963), (COL!); L. Uribe U. 4006-Colombia, Dept. Cundinamarca, Mpio. San Antonio del Tequendama, Santandercito, subiendo a Laguna Seca, alt. 1,900 m (7 Apr 1962), (COL!); Cuatrecasas, Schultes 7 E. Smith 12805-Colombia, Dept. Norte de Santander, Mpio. Toledo, Cordillera Oriental. Hoya de Samaria, alt. 2,000-2,100 m (30 Oct 1941), (COL!); G. Huertas \& L.A. Camargo G. 6971-Colombia, Dept. Santander, Mpio. La Paz, Cordillera Oriental, Alrededores del Hoyo del Aire, alt. 1,943 m (7 Nov 1975), (COL!); Davides \& A.C. Gonzalez 22277-Venezuela, Est. Táchira, Distr. Junín, La Pena, along Delicias-Rubio Highway, alt. 1900 m (15 Nov 1982), (COL!).

Ponthieva castanedoi Szlach. \& Kolan. sp. nov. (Fig. 4)

This species appears to be related to P. parvilabris (Lindl.) Rchb.f. from which it differs by having shortly clawed petals, obliquely ovate lateral sepals, auriculated, ecallose lip set on claw with upcurved margins.

Type Cuatrecasas \& Romero-Castaneda 24716-Colombia, Dept. Magdalena, Sierra Nevada de Santa Marta. SE slopes, Hoya del Rio Donachui, Cancurua, fields and forests, alt. 2,400-2,650 m (10-11 Oct 1959), (COL! holotype).

Plants 14-28 cm tall. Leaves basal, rosulate, petiolate; petiole to $3.5 \mathrm{~cm}$ long, narrow; blade to $5 \mathrm{~cm}$ long and $2.3 \mathrm{~cm}$ wide, ovate, oblong-lanceolate to oblong-ovate, acute. Scape delicate, erect, glabrous, glandular below and within inflorescence, with three cauline sheaths. Flowers small. Floral bracts $6 \mathrm{~mm}$ long, lanceolate, glabrous. 
A
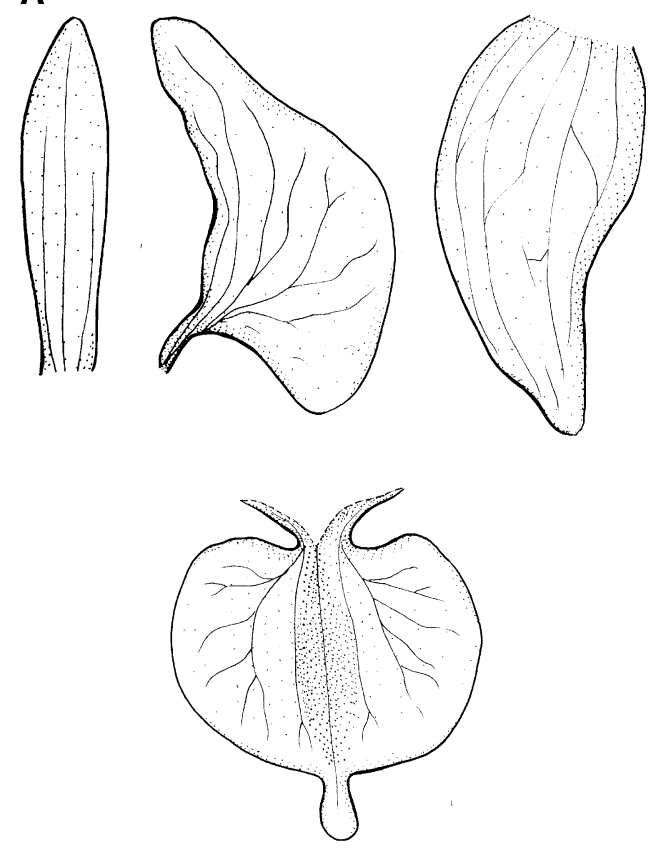

C
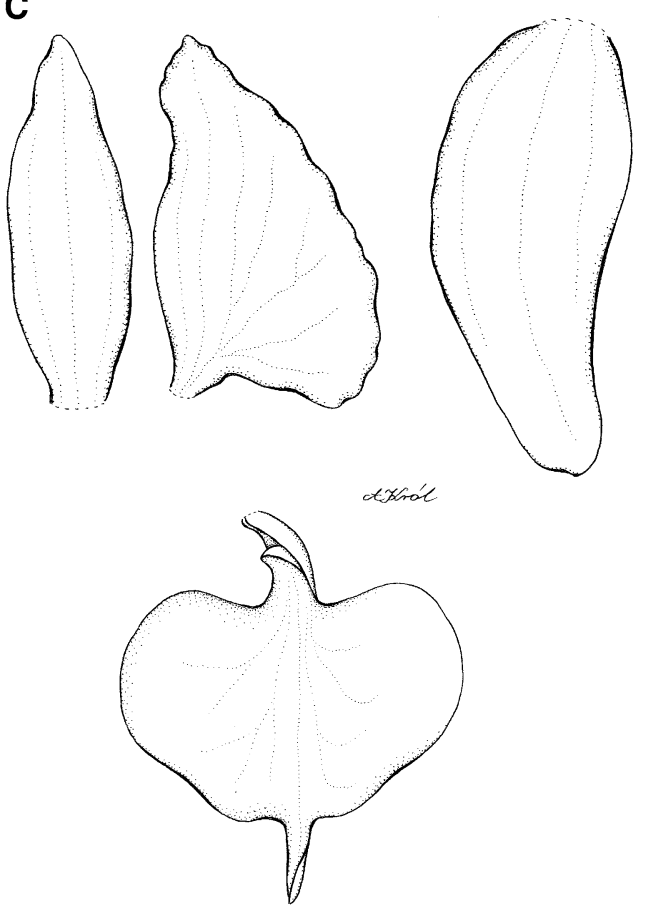

B
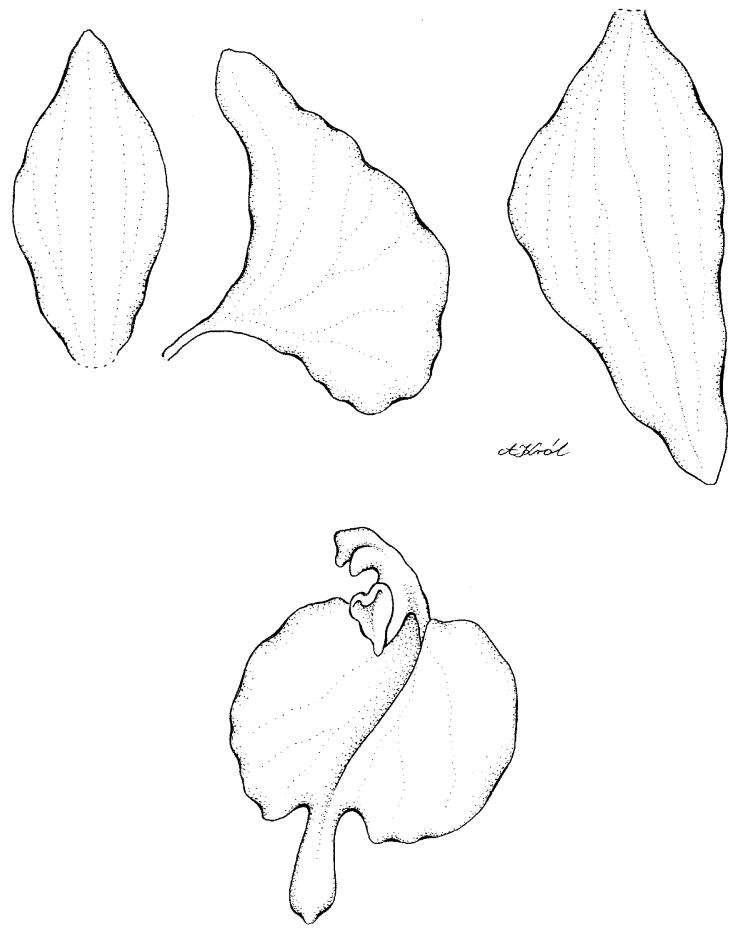

Fig. 3 Comparison of the floral characters of Ponthieva camargoi (a), P. pseudoracemosa (b) and P. racemosa (c) [drawn by P. Baranow and A. Król]

Pedicellate ovary to $11 \mathrm{~mm}$ long, densely glandular. Sepals sparsely glandular. Dorsal sepal $6 \mathrm{~mm}$ long, $3 \mathrm{~mm}$ wide, ovate-deltoid, widest near the middle, subobtuse, with 5 , sparsely anastomozing nerves. Lateral sepals $6 \mathrm{~mm}$ long, $3.8 \mathrm{~mm}$ wide, obliquely ovate, subobtuse, somewhat falcate, free to the base, 5-nerved. Petals clawed; claw free part 1-1.2 mm long, narrow; lamina $4.6 \mathrm{~mm}$ long, $2.3 \mathrm{~mm}$ wide, obliquely oblong-ovate, obtuse at both ends. Lip clawed; claw-free part $1.5 \mathrm{~mm}$ long, broadly ovate above narrow base, margins upcurved, forming a kind of channel 
Fig. 4 Ponthieva castanedoidissected perianth. a Dorsal sepal, b petal, c lateral sepal, d lip. Scale bar $3 \mathrm{~mm}$ [holotype; drawn by P. Baranow]
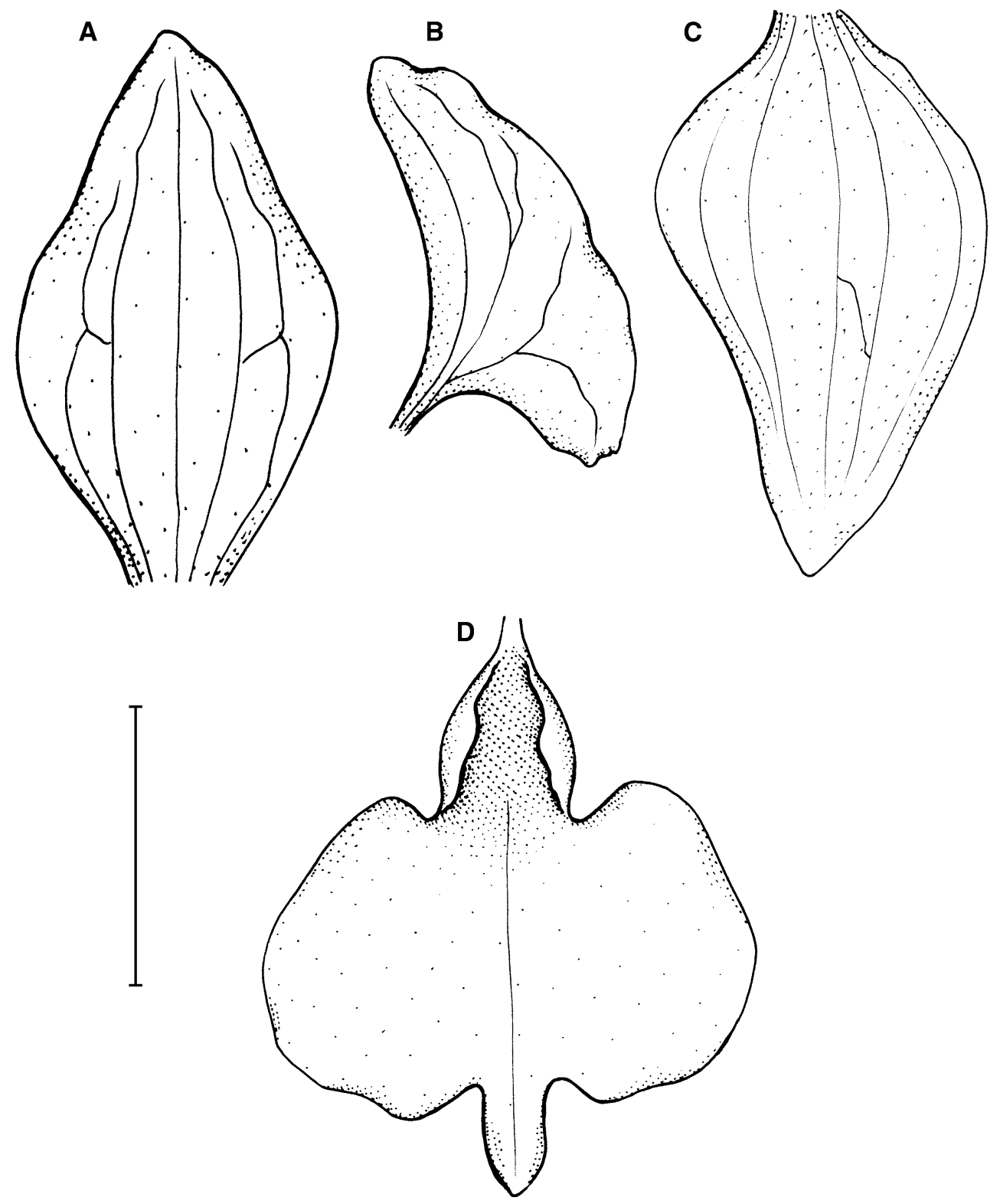

directed to the lip base; lamina $2.5 \mathrm{~mm}$ long, $5 \mathrm{~mm}$ wide, transversely elliptic in general outline, auriculate or cordate at the base, concave, glabrous, apical projection $0.5 \mathrm{~mm}$ long, linear, obtuse, appearing at the bottom of shallow sinus. Gynostemium $2.6 \mathrm{~mm}$ long.

Etymology Dedicated to Romero-Castaneda, co-collector of the type specimen.

Distribution, habitat and ecology So far known only from the Santa Marta mountains where it was found at $2,400-2,600 \mathrm{~m}$ in the fields and forests. Flowering in October.

Taxonomic notes In some cases, this species is similar to its Ecuadorian-Peruvian congener- $P$. parvilabris (Lindl.) Rchb.f. Both species differ, however, in the details of flowers segments. Although, similar in general outline, the lip makes them easily separable. The lip of $P$. castanedoi is prominently auriculate basally, and devoid of any calli, the claw margins are upcurved forming a channel directed to the base of the lip. In P. parvilabris lip claw is semiterete, lamina possesses cuneate base, and a pair of keel-like, fleshy calli at base. Additionally, petal's claw of the new species is shorter than lower lobe, whereas in P. parvilabris petal's claw is as long as or longer than lower lobe. Lateral sepals of $P$. castanedoi are obliquely ovate versus obliquely elliptic-ovate in $P$. parvilabris (Fig. 5).

Ponthieva cesarensis Szlach. \& Kolan. sp. nov. (Fig. 6)

Plants similar to $P$. similis C.Schweinf., but differ in having lateral sepals free to the base, petals with cuneate base, and lip with obscure callus. 

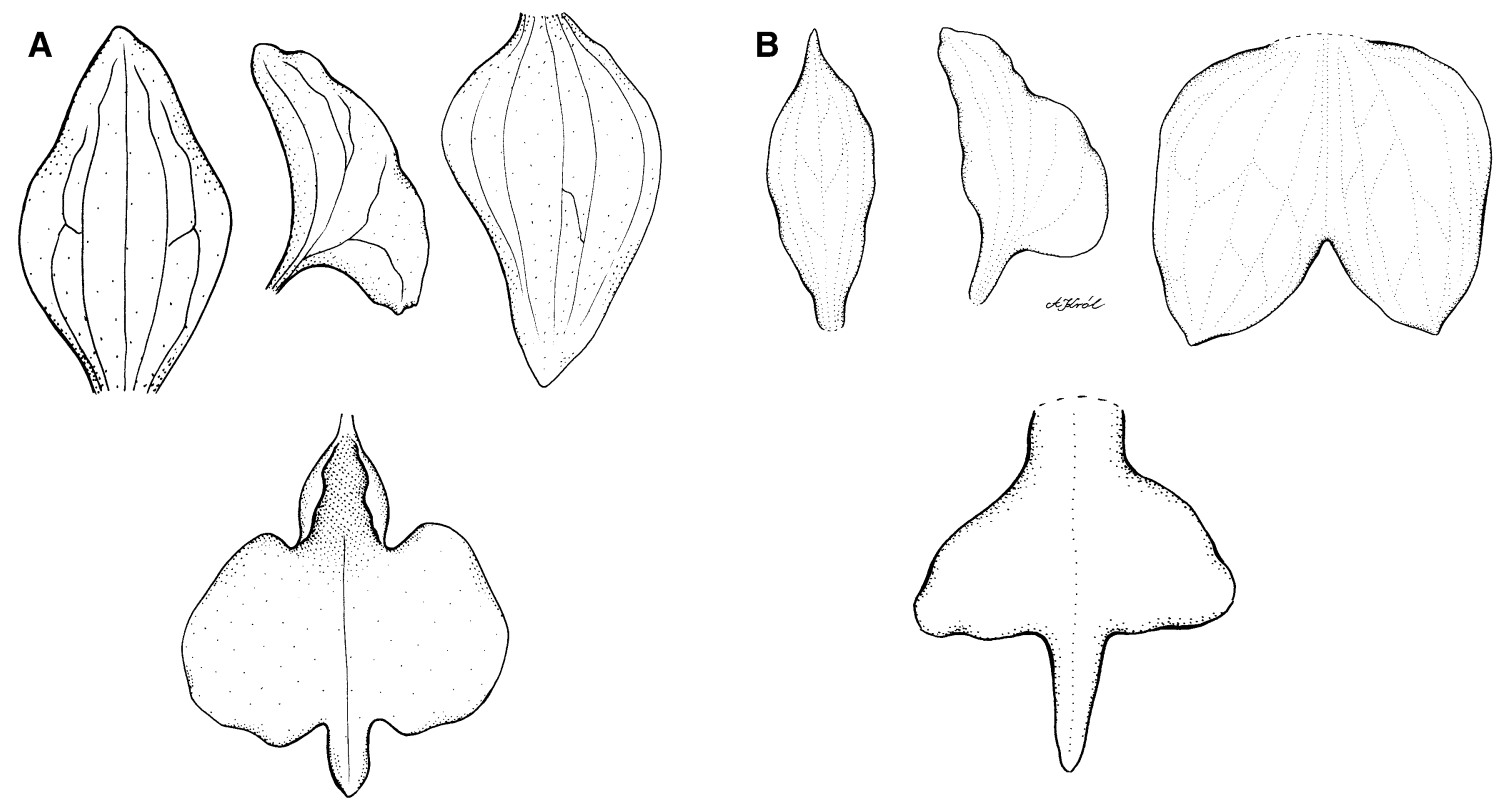

Fig. 5 Comparison of the floral characters of Ponthieva castanedoi (a) and P. parvilabris (b) [drawn by P. Baranow and A. Król]

Type O. Rivera Diaz, N.J. Garzon, C.A. Vargas \& S. Corzo M. 2849-Colombia, Dept. Cesar, Mpio. Agustin Codazzi. Serrania de Perijá. Vereda Siete de Agosto. Colecciones camino al páramo de Tres Tetas, desde la Cuchilla Macho Solo. Zona de subparamo arbustivo con suelos arenoso pedregosos de color blanco, dominado por Asteraceae y Ericaceae, $9^{\circ} 57^{\prime} 03.0^{\prime \prime}-24.4^{\prime \prime} \mathrm{N} 73^{\circ} 02^{\prime} 04.3^{\prime \prime}-$ 00'58.9"W, alt. 1,884-2,551 m (10 Dec 2005), (COL! holotype).

Plants to $22 \mathrm{~cm}$ tall. Leaves 3 , basal, rosulate, petiolate; petiole to $5 \mathrm{~cm}$ long, narrow; blade to $18 \mathrm{~cm}$ long and $4 \mathrm{~cm}$ wide, oblanceolate to oblong-oblanceolate, acute, somewhat oblique, margins densely hirsute, blade sparsely hirsute. Scape hirsute. Flowers small. Floral bracts to $10 \mathrm{~mm}$ long, densely hirsute. Pedicellate ovary to $12 \mathrm{~mm}$ long, densely hirsute. Sepals sparsely hirsute. Dorsal sepal $11 \mathrm{~mm}$ long, $3.2 \mathrm{~mm}$ wide, oblong-lanceolate, subacute, 5-nerved. Lateral sepals $12 \mathrm{~mm}$ long, $6.5 \mathrm{~mm}$ wide, obliquely elliptic-ovate with lanceolate, acute apex, 6-nerved. Petals clawed; claw free part 1.5-2 mm long; lamina $8 \mathrm{~mm}$ long, $2.5 \mathrm{~mm}$ wide, cuneate at base, obliquely ovate-lanceolate, obtuse. Lip subsessile, $4 \mathrm{~mm}$ long, $2 \mathrm{~mm}$ wide, oblong-obovate in outline, rounded at apex with small triangular projection at the apex, conduplicate, concave in the centre, with single, branching nerve, basal callus roof- like, truncate, with sides decurrent on lip margins. Gynostemium $2.5 \mathrm{~mm}$ long.

Etymology In reference to the name of the Colombian department of Cesar where the plants of this species were found.

Distribution, habitat and ecology So far known only from the northernmost Andes on the border between Colombia and Venezuela. It was found growing in subparamo with vegetation dominated by Asteraceae and Ericaceae, in sandy and rocky soils at about up to about $2,550 \mathrm{~m}$. It was also found at lower elevations in the vegetation dominated by Anacardiaceae (Toxicodendron), Araliaceae (Oreopanax), Cunoniaceae (Weinmannia), Burseraceae (Bursera).

Taxonomic notes This species appears to be similar to $P$. similis C.Schweinf. and is widely distributed from Peru to Colombia. The species is easily separable by some floral characters-free lateral sepals found in $P$. cesarensis, versus lateral sepals connate almost to the apex in $P$. similis, cuneate base of petals in the new species versus unguiculate base in its closest congenier. Additionally, the lip callus is very prominent in $P$. similis and very obscure in P. cesarensis Fig. 7.

Representative specimens O. Rivera Diaz, N.J. Garzon, C.A. Vargas \& S. Corzo M. 2849-Colombia, Dept. Cesar, 
Fig. 6 Ponthieva cesarensisdissected perianth. a Dorsal sepal, b petal, c lateral sepal, d lip, e lip (side view). Scale bars $2 \mathrm{~mm}$ [holotype; drawn by P. Baranow]
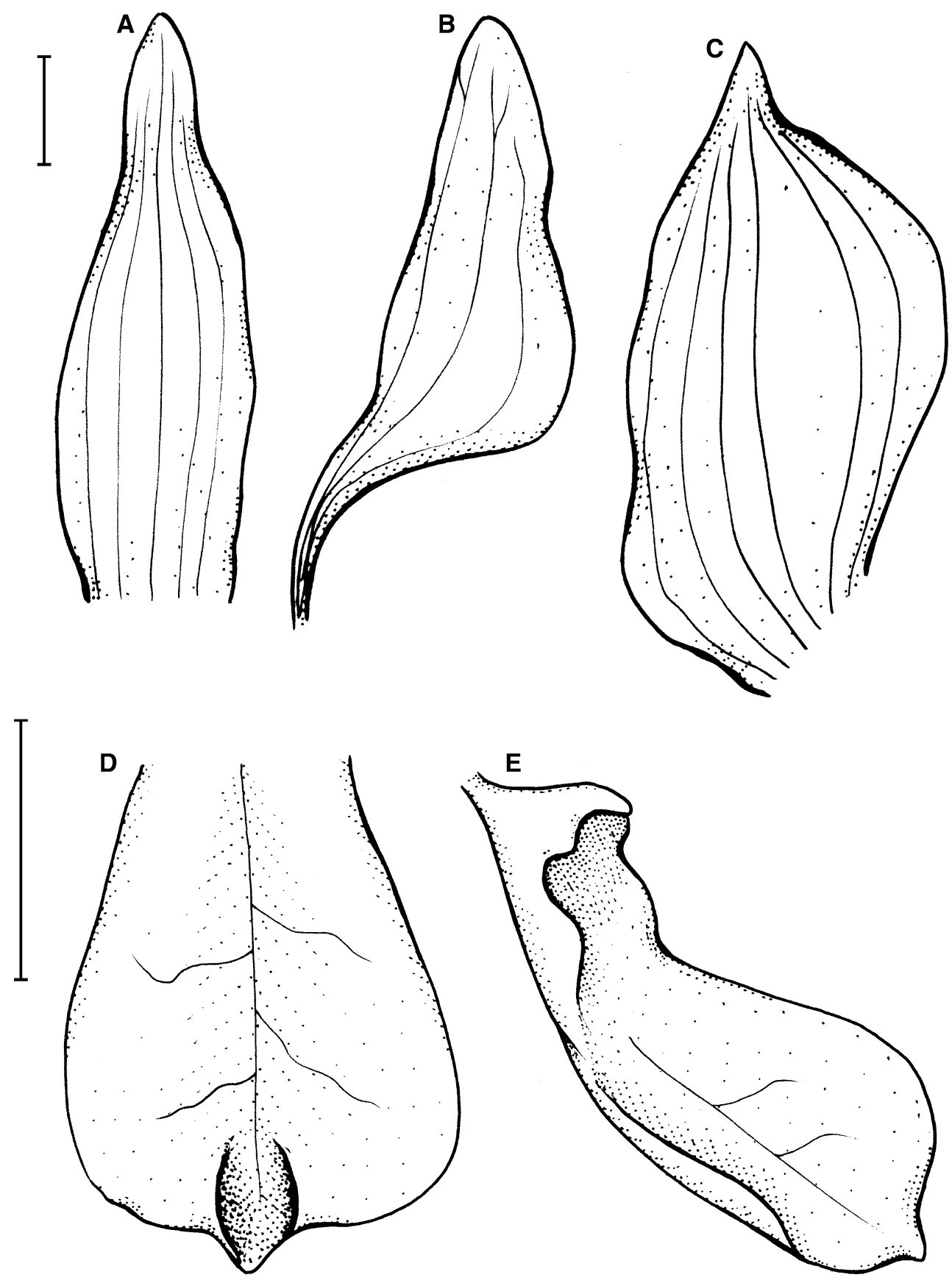

Mpio. Agustin Codazzi, Serrania de Perijá. Vereda Siete de Agost. Colecciones camino al páramo de Tres Tetas, desde la Cuchilla Macho Solo. Zona de subparamo arbustivo con suelos arenoso pedregosos de color blanco, dominado por Asteraceae y Ericaceae, $9^{\circ} 57^{\prime} 03.0^{\prime \prime}-$ $24.4^{\prime \prime} \mathrm{N}, 73^{\circ} 02^{\prime} 04.3^{\prime \prime}-00^{\prime} 58.9^{\prime \prime} \mathrm{W}$, alt. $1,884-2,551 \mathrm{~m}(10$ Dec 2005), (COL!); O. Rivera Diaz, J. Contreras, N.J.
Garzon, C.A. Vargas, O. Garay G. \& E. Zuluaga 3143-Colombia, Dept. Cesar, Mpio. Serrania de Perijá. Vereda Siete de Agosto. Bosque arriba de la Cuchilla Macho Solo, dominado por Toxicodendron, Oreopanax, Weinmannia, Bursera con dosel antre 15 years 20 months, $9^{\circ} 57^{\prime} 09.0^{\prime \prime}-10.6^{\prime \prime} \mathrm{N}, 73^{\circ} 01^{\prime} 45.9^{\prime \prime}-34.3^{\prime \prime} \mathrm{W}$, alt. 1,898-2,200 m (27 Feb 2006), (COL!). 

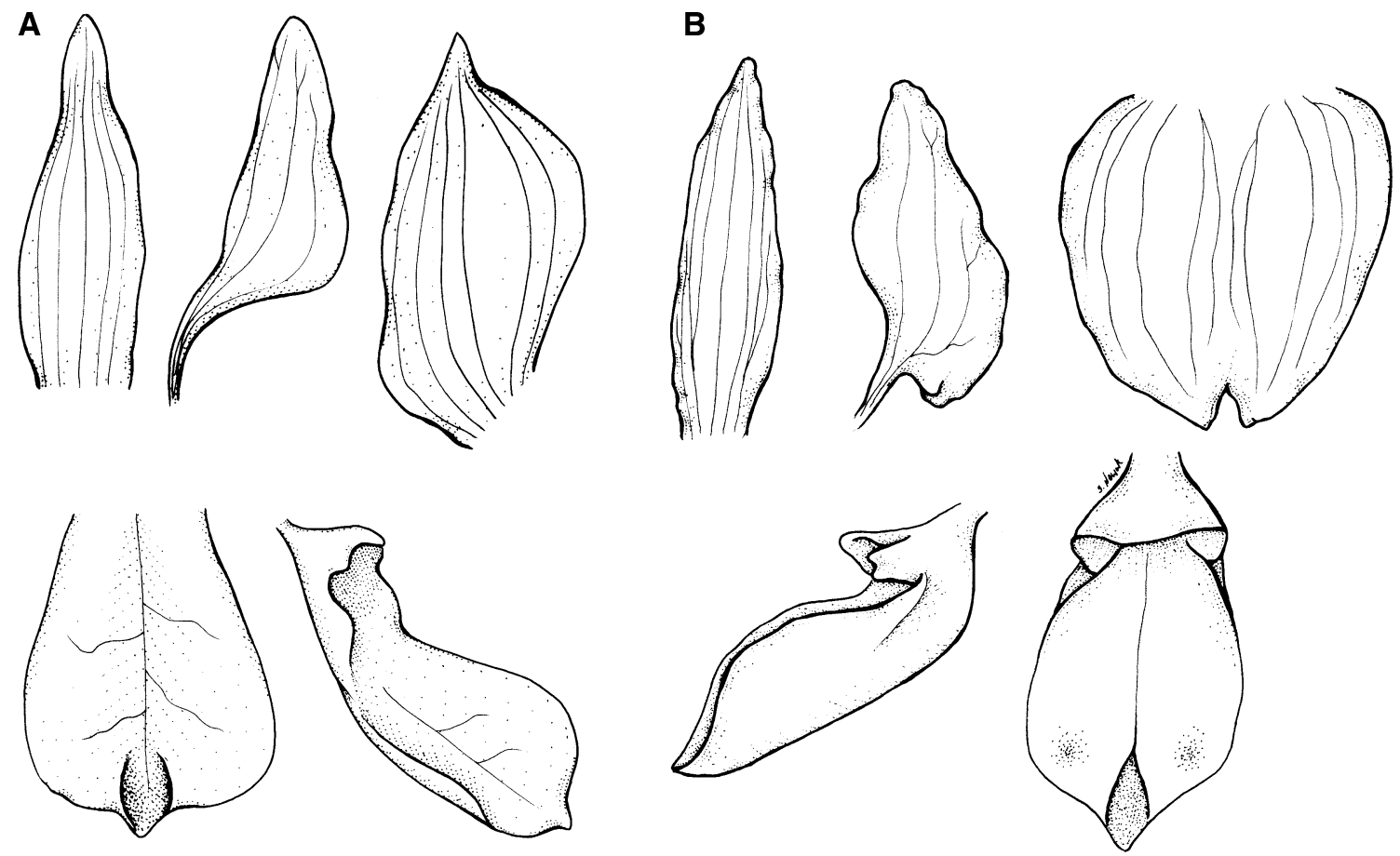

Fig. 7 Comparison of the floral characters of Ponthieva cesarensis (a) and P. similis (b) [drawn by P. Baranow and S. Nowak]

Acknowledgments The curators and staff of the cited herbaria are thanked for their kind hospitality and assistance during visits and for making specimens available on loan. We are grateful to Anna Król, Przemysław Baranow and Sławomir Nowak for preparing the illustrations. The research described here has been supported by the Polish Ministry of Science and Higher Education (research grant no. 8124/B/ PO1/2011/40).

Open Access This article is distributed under the terms of the Creative Commons Attribution License which permits any use, distribution, and reproduction in any medium, provided the original author(s) and the source are credited.

\section{References}

Ames O, Correll DS (1952) Orchids of Guatemala (I). Fieldiana Bot 26(1):87-94

Brown R (1813) Orchidaceae (as Classis XX, Gynandria, Monandria-Dinandria). Hortus Kew [W. Aiton] 5:188-220
Carnevali G, Ramírez-Morillo IM, Vargas CA (2003) Ponthieva. In: Steyermark JE, Berry PE, Yatskievych K, Holst BK (eds) Flora of the Venezuelan Guayana, vol 7. Myrtaceae-Plumbaginaceae. Missouri Botanical Garden Press, St. Louis, pp 532-533

Ortiz VP, Uribe VC (2007) Galería de Orquídeas de Colombia (CD edition). Asociación Bogotana de Orquideología, Bogotá

Salazar GA, Cabrera LI, Madriñán S, Chase MW (2009) Phylogenetic relationships of Cranichidinae and Prescottiinae (Orchidaceae, Cranichideae) inferred from plastid and nuclear DNA sequences. Ann Bot 104:403-416

Salazár GA, Chase MW, Soto MA, Ingrouille M (2003) Phylogenetics of Cranichideae with emphasis on Spiranthinae (Orchidaceae, Orchidoideae): evidence from plastid and nuclear DNA sequences. Am J Bot 90(5):777-795

Szlachetko DL (1995) Systema Orchidalium. Fragm Flor Geobot Suppl 3:1-152

Szlachetko DL, Rutkowski P (2000) Gynostemia Orchidalium: Volume 1. Apostasiaceae, Cypripediaceae, Orchidaceae (Thelymitroideae to Vanilloideae). Acta Bot Fen 169:294-295 